\title{
Plasma Prolidase Activity and Oxidative Stress in Patients with Parkinson's Disease
}

\author{
Akhilesh Kumar Verma, ${ }^{1}$ Janak Raj, ${ }^{2}$ Vivek Sharma, ${ }^{2}$ Tej Bali Singh, ${ }^{3}$ \\ Shalabh Srivastava, ${ }^{4}$ and Ragini Srivastava ${ }^{1}$ \\ ${ }^{1}$ Department of Biochemistry, Institute of Medical Sciences, Banaras Hindu University, Varanasi, Uttar Pradesh 221005, India \\ ${ }^{2}$ Department of Neurosurgery, Institute of Medical Sciences, Banaras Hindu University, Varanasi, Uttar Pradesh 221005, India \\ ${ }^{3}$ Division of Biostatistics, Department of Community Medicine, Institute of Medical Sciences, Banaras Hindu University, \\ Varanasi, Uttar Pradesh 221005, India \\ ${ }^{4}$ Department of Oral Pathology, Jaipur Dental College, Jaipur, Rajasthan 302020, India
}

Correspondence should be addressed to Ragini Srivastava; ragsriv@gmail.com

Received 17 September 2014; Revised 15 January 2015; Accepted 26 January 2015

Academic Editor: Mohammad M. Khan

Copyright (c) 2015 Akhilesh Kumar Verma et al. This is an open access article distributed under the Creative Commons Attribution License, which permits unrestricted use, distribution, and reproduction in any medium, provided the original work is properly cited.

Prolidase deficiency has been related to mental retardation and oxidative stress. The study aimed to observe plasma prolidase activity (PPA), total oxidant status (TOS), total antioxidant status (TAS), and oxidative stress index (OSI) in patients with Parkinson's disease (PD). 240 subjects with PD and 150 healthy volunteers were considered as cases and controls, respectively. PPA, TOS, TAS, and OSI were measured spectrophotometrically. PPA and TAS in cases were more significantly decreased than controls $(P<0.01)$, while TOS and OSI were significantly increased $(P<0.001)$. In cases, nonsignificant, positive correlation was observed between PPA and TOS and OSI while significant, negative correlation was observed between PPA and TAS $(P=0.047)$. PPA in cases was nonsignificantly decreased with increased duration of $\mathrm{PD}(P=0.747)$ while TAS was significantly decreased $(P<0.001)$ and TOS and OSI were significantly increased $(P<0.001)$. It was observed that higher age groups had decreased PPA, and TAS and increased TOS and OSI compared to lower age groups in cases. In summary, patients with PD have decreased PPA and increased oxidative stress compared to healthy volunteers. PPA was associated with oxidative stress markers in patients with PD. Decreased PPA and TAS and increased TOS and OSI were associated with progression of disease and higher age.

\section{Introduction}

Parkinson's disease (PD) is the second most common neurodegenerative disorder that mostly affects old people [1]. Some decades ago, the pathogenesis of PD was not clear. But with time, evidences like oxidative damage, inflammation, and nitrosative stress are found to be contributing factors [1-3]. Increased oxidative stress and inflammatory mediators such as reactive oxygen species, reactive nitrogen species, proinflammatory cytokines, and complement component have been reported in substantia nigra as well as in cerebrospinal fluid of patients with PD [3]. Thus, proinflammatory response can lead to the inflammation mediated degeneration of neurons in patients with $\operatorname{PD}[3,4]$.
A cytosolic exopeptidase, prolidase, cleaves iminopeptides at carboxy-terminal proline or hydroxy-proline and is actively involved in collagen metabolism [5]. It has been reported that prolidase activity and inflammation can be correlated to each other during the process of fibrosis [6]. Prolidase activity has been also associated with oxidative stress in different diseases [7-11]. A report of Mantle et al. suggested that proline endopeptidase activity decreases in brain tissue of patients with Alzheimer's disease, Parkinson's disease, and Lewy body dementia compared to healthy individuals [12]. In the case of Alzheimer's disease, brain tissue proline endopeptidase activity decreased [12], while serum prolidase (proline exopeptidase) activity was increased with increase in oxidative stress [7]. It is well accepted that, as 
Alzheimer's disease, oxidative stress is found to be increased in the patients with Parkinson's disease (PD) $[7,13]$. There are no previous studies present in literature regarding prolidase activity in the patients with PD. Thus for evaluating plasma proline exopeptidase activity in patients with $\mathrm{PD}$, we aimed to investigate the correlation between plasma prolidase activity and oxidative stress markers (including total oxidant status, total antioxidant status, and oxidative stress index) in patients with PD.

\section{Materials and Methods}

The study was carried out in the Department of Biochemistry, Institute of Medical Sciences, Banaras Hindu University, Varanasi, India. The cases were provided by the department of neurosurgery. The study was approved by our institutional ethical committee and informed consent was taken from every studied subject.

2.1. Patients Selection. A total 390 subjects of cases and controls of matched age and sex were selected. Out of 390 subjects, 240 patients were cases of Parkinson's disease (180 males and 60 females) who were enrolled in Outpatients Department (OPD) of Neurosurgery, Institute of Medical Sciences, Banaras Hindu University, Varanasi, India. The age group was between 35 and 70 years with mean of $56.39 \pm 8.92$ years. The diagnosis of Parkinson's disease was made by our expert clinician. The range of duration of disease for PD was from 6 months to 14 years. 150 healthy subjects (114 males and 36 females of age group between 37 and 72 years $(56.83 \pm$ 11.36 years)) with no other disease were considered as control group.

2.2. Collection and Storage of Plasma. Venous blood was collected in EDTA tubes. Plasma was immediately separated from the cells by centrifugation at $3000 \mathrm{rpm}$ for $10 \mathrm{~min}$. Plasma samples for the measurement of prolidase activity and oxidative stress markers were stored at $-80^{\circ} \mathrm{C}$ until being used. Each sample was thawed at room temperature for performing every test; repeated thaw was avoided.

2.3. Measurement of Plasma Prolidase Activity (PPA). Diluting solution ( $1 \mathrm{mM} \mathrm{MnCl}_{2}$ in $6 \mathrm{mM}$ Tris $\mathrm{HCl}$ buffer ( $\mathrm{pH} 7.8-$ $8.0)$ ), standard proline solution $(650 \mu \mathrm{mol} / \mathrm{L}$ proline solutions in $0.45 \mathrm{~mol} / \mathrm{L}$ trichloroacetic acid), and glycyl-L-proline solution $(94 \mathrm{mmol} / \mathrm{L}$ Gly-l-Pro solution in $0.05 \mathrm{~mol} / \mathrm{L}$ Tris $\mathrm{HCl}$ buffer containing $1 \mathrm{mmol} / \mathrm{L}$ of $\mathrm{MnCl}_{2}$ ( $\mathrm{pH}$ 7.8-8.0)) were prepared. Chinard's reagent was prepared by mixing of $600 \mathrm{~mL}$ of glacial acetic acid with $400 \mathrm{~mL}$ of $6 \mathrm{~mol} / \mathrm{L}$ orthophosphoric acid and $25 \mathrm{~g}$ of ninhydrin dissolved in the mixture at $70^{\circ} \mathrm{C}$ (in water bath). Before preparation of Chinard's reagent, $6 \mathrm{~mol} / \mathrm{L}$ orthophosphoric acid was prepared by mixing of $407 \mathrm{~mL}$ of orthophosphoric acid (85\%, $d=1.7)$ in $593 \mathrm{~mL}$ of distilled water.

Procedure. Plasma was diluted six times with diluting solution and preincubated for 24 hours at $37^{\circ} \mathrm{C}$. For enzymatic reaction, experimental tube and control tube were selected.
Experimental tube contained $100 \mu \mathrm{L}$ of $94 \mathrm{mmol} / \mathrm{L}$ Gly-lPro solution and $100 \mu \mathrm{L}$ of diluted and preincubated plasma, while control tube contained only $100 \mu \mathrm{L}$ of diluted and preincubated plasma. Both the tubes were incubated for 30 minutes at $37^{\circ} \mathrm{C}$, and then the reaction was stopped by adding of $1 \mathrm{~mL}$ of $0.45 \mathrm{~mol} / \mathrm{L}$ trichloroacetic acid. After the reaction is stopped, $100 \mu \mathrm{L}$ of diluted and non-incubated plasma was added in control tube. After this, supernatant was separated by centrifugation at $2000 \mathrm{rpm}$ for 5 minutes. $0.5 \mathrm{~mL}$ of each tube supernatant was used for the measurement of enzyme activity.

Again four tubes were selected as blank tube, standard tube, experimental tube, and control tube for enzyme activity measurement. $1 \mathrm{~mL}$ of Chinard's reagent and $1 \mathrm{~mL}$ of glacial acetic acid were added to each tube. Then, $0.5 \mathrm{~mL}$ of above supernatant was added to respective experimental and control tube. Instead of supernatant, $0.5 \mathrm{~mL}$ of trichloroacetic acid $(0.45 \mathrm{~mol} / \mathrm{L})$ and $0.5 \mathrm{~mL}$ of standard proline solution were added to the blank tube and standard tube, respectively. After this, all tubes were incubated at $90^{\circ} \mathrm{C}$ in water bath for 10 minutes for complex formation. Absorbance was measured at $515 \mathrm{~nm}$. Spectrophotometer was adjusted to zero with the blank. PPA was measured according to following formula [14]:

$$
\frac{E-C}{S} \times[S] \times 2.4=\mathrm{mmol} \cdot \mathrm{min}^{-1} \cdot \mathrm{L}^{-1} .
$$

$E$ is experimental tube absorbance, $C$ control tube absorbance, $S$ standard tube absorbance, and $[S]$ concentration of the substrate in $\mathrm{mmol} / \mathrm{L}(94 \mathrm{mmol} / \mathrm{L})$. PPA was represented as $\mathrm{mmol} \mathrm{min}^{-1} \mathrm{~L}^{-1}$.

2.4. Measurements of Total Antioxidant Status (TAS). Blood plasma TAS was measured by the colorimetric method developed by Erel, 2004 [15]. $200 \mu \mathrm{L}$ of reagent-1 (o-dianisidine $(10 \mathrm{mM})$, ferrous ion $(45 \mu \mathrm{M})$ in the Clark and Lubs solution (75 mM, pH 1.8)) was added to $5 \mu \mathrm{L}$ of plasma and then $10 \mu \mathrm{L}$ of reagent- $2\left(7.5 \mathrm{mM}\right.$ of $\mathrm{H}_{2} \mathrm{O}_{2}$ in the Clark and Lubs solution) was added. Absorbance was taken at $444 \mathrm{~nm}$. Color formation was calibrated with Trolox and results were expressed in millimolar Trolox equivalent per liter ( $\mathrm{mmol}$ Trolox Eq/L).

2.5. Measurements of Total Oxidant Status (TOS). Blood plasma TOS was measured by the colorimetric method developed by Erel, 2005 [16]. $225 \mu \mathrm{L}$ of reagent-1 (150 $\mu \mathrm{M}$ xylenol orange, $140 \mathrm{mM} \mathrm{NaCl}$, and $1.35 \mathrm{M}$ glycerol in $25 \mathrm{mM} \mathrm{H}_{2} \mathrm{SO}_{4}$ solution, $\mathrm{pH} 1.75$ ) and $11 \mu \mathrm{L}$ of reagent-2 (5 mM ferrous ion and $10 \mathrm{mM} o$-dianisidine in $25 \mathrm{mM} \mathrm{H}_{2} \mathrm{SO}_{4}$ solution) were added to $35 \mu \mathrm{L}$ of plasma in sequence. Absorbance was taken as end point measurement, bichromatic at $560 \mathrm{~nm}$ (main wavelength) and $800 \mathrm{~nm}$ (secondary wavelength). The first absorbance was taken after mixing of reagent- 1 and plasma (as blank) and last absorbance was taken after 4 minutes of mixing of reagent- 2 . The assay was calibrated with $\mathrm{H}_{2} \mathrm{O}_{2}$ and the results were expressed in micromolar $\mathrm{H}_{2} \mathrm{O}_{2}$ equivalent per liter $\left(\mu \mathrm{mol} \mathrm{H}_{2} \mathrm{O}_{2} \mathrm{Eq} / \mathrm{L}\right)$. 
TABLE 1: Representation of plasma prolidase activity, total oxidant status, total antioxidant status, and oxidative stress index in cases and controls.

\begin{tabular}{|c|c|c|c|c|}
\hline Conditions/parameters & $\begin{array}{l}\text { Plasma prolidase activity } \\
\left(\mathrm{mmol} \mathrm{min}^{-1} \mathrm{~L}^{-1}\right)\end{array}$ & $\begin{array}{l}\text { Total oxidant status } \\
\left(\mu \mathrm{mol} \mathrm{H}_{2} \mathrm{O}_{2} \mathrm{Eq} / \mathrm{L}\right)\end{array}$ & $\begin{array}{c}\text { Total antioxidant status } \\
(\mathrm{mmol} \text { Trolox Eq/L) }\end{array}$ & $\begin{array}{c}\text { Oxidative stress index } \\
\text { (arbitrary unit) }\end{array}$ \\
\hline $\begin{array}{l}\text { Cases } \\
(n=240)\end{array}$ & $\begin{array}{c}40.30 \pm 27.13 \\
(R=1.47 \text { to } 88.45 \\
\text { median }=39.13) \\
\end{array}$ & $\begin{array}{c}16.55 \pm 3.28 \\
(R=9.80 \text { to } 28.91)\end{array}$ & $\begin{array}{c}1.69 \pm 0.47 \\
(R=0.95 \text { to } 2.76)\end{array}$ & $\begin{array}{c}11.02 \pm 5.03 \\
(R=3.55 \text { to } 30.43)\end{array}$ \\
\hline $\begin{array}{l}\text { Controls } \\
(n=150)\end{array}$ & $\begin{array}{c}61.70 \pm 15.92 \\
(R=35.24 \text { to } 105.97 \\
\text { median }=58.86)\end{array}$ & $\begin{array}{c}12.61 \pm 2.57 \\
(R=8.75 \text { to } 17.11)\end{array}$ & $\begin{array}{c}1.93 \pm 0.40 \\
(R=1.18 \text { to } 2.56)\end{array}$ & $\begin{array}{c}7.13 \pm 3.06 \\
(R=3.37 \text { to } 14.50)\end{array}$ \\
\hline $\begin{array}{l}P \text { value } \\
\text { (two-tailed) }\end{array}$ & $<0.001^{* *}$ & $<0.001^{*}$ & $0.006^{*}$ & $<0.001^{*}$ \\
\hline
\end{tabular}

Significant (Sig.) $P$ value less than 0.05 was considered. Data are mean \pm standard deviation, $n=$ number, $R=$ range, $*=$ value according to Student's $t$-test, and $* *=$ value according to Mann-Whitney $U$ test.

2.6. Measurements of Oxidative Stress Index (OSI). OSI was calculated as ratio of TOS $\left(\mu \mathrm{mol} \mathrm{H}_{2} \mathrm{O}_{2} \mathrm{Eq} / \mathrm{L}\right)$ to TAS (mmol Trolox Eq/L) [11, 14].

2.7. Statistical Analysis. Standard statistical methods, Student's $t$-test, ANOVA, and Pearson's correlation were used. Nonparametric Mann-Whitney $U$ test, Spearman's rho correlation, and Kruskal Wallis test were used if distributions were not normal. A $P$ value less than $0.05(P<0.05)$ was considered significant. Data were representation as mean $\pm \mathrm{SD}$ (standard deviation). All statistical calculations were done by use of SPSS 16.0 and Graph pad software. Interassay and intraassay precision performances of the assay were calculated for PPA, TAS, and TOS. Interassay and intraassay $\%$ of coefficient of variation for PPA, TAS, and TOS were $8.65 \%$ and $5.00 \%, 7.82 \%$ and $4.00 \%$, and $6.51 \%$ and $4.68 \%$ observed, respectively.

\section{Results}

3.1. Plasma Prolidase Activity (PPA). Our results showed that plasma prolidase activity in cases $(40.30 \pm 27.13 \mathrm{mmol}$ $\min ^{-1} \mathrm{~L}^{-1}$ with range 1.47 to $88.45 \mathrm{mmol} \mathrm{min}^{-1} \mathrm{~L}^{-1}$ ) was more significantly decreased than controls $(61.70 \pm 15.92$ mmol min ${ }^{-1} \mathrm{~L}^{-1}$ with range 35.24 to $105.97 \mathrm{mmol} \mathrm{min}^{-1} \mathrm{~L}^{-1}$ ) $(P<0.001$, Table 1$)$.

3.2. Total Antioxidant Status (TAS). TAS levels in cases $(1.69 \pm$ $0.47 \mathrm{mmol}$ Trolox Eq/L, with range 0.95 to $2.76 \mathrm{mmol}$ Trolox $\mathrm{Eq} / \mathrm{L})$ were more significantly decreased than healthy controls $(1.93 \pm 0.40 \mathrm{mmol}$ Trolox Eq/L with range 1.18 to $2.56 \mathrm{mmol}$ Trolox Eq/L) $(P=0.006$, Table 1$)$.

3.3. Total Oxidant Status (TOS) and Oxidative Stress Index (OSI). TOS and OSI levels in cases $\left(16.55 \pm 3.28 \mu \mathrm{mol} \mathrm{H}_{2} \mathrm{O}_{2}\right.$ $\mathrm{Eq} / \mathrm{L}$ and $11.02 \pm 5.03 \mathrm{AU}$, resp.) were more significantly increased than controls $\left(12.61 \pm 2.57 \mu \mathrm{mol} \mathrm{H}_{2} \mathrm{O}_{2} \mathrm{Eq} / \mathrm{L}\right.$ and $7.13 \pm$ 3.06 AU, resp.) (all $P<0.001$, Table 1).

3.4. Correlative Observations. In cases, no correlations were observed between PPA and TOS and OSI $(r=0.202, P=$ 0.128 and $r=0.246, P=0.063$, resp.), while significant negative correlation was observed between PPA and TAS $(r=$ $-0.262, P=0.047)$. In cases, strong negative and significant correlation were observed between TOS versus TAS and TAS versus OSI $(r=-0.933, P<0.001$ and $r=-0.912, P<0.001$, resp.), while significant, strong, and positive correlation was observed between TOS and OSI $(r=0.962, P<0.001)$.

3.5. Altered Values of PPA, TAS, TOS, and OSI with Duration of PD. For the evaluation of PPA, TAS, TOS, and OSI with disease duration, total 240 cases were categorized as disease duration $\leq 2$ years (140 subjects) and disease duration greater than 2 years (100 subjects, Table 2$)$. PPA in cases with disease duration greater than 2 years $\left(38.44 \pm 25.43 \mathrm{mmol} \mathrm{min}^{-1} \mathrm{~L}^{-1}\right)$ were nonsignificantly decreased compared to disease duration $\leq 2$ years $\left(43.13 \pm 29.89 \mathrm{mmol} \mathrm{min}^{-1} \mathrm{~L}^{-1}\right)(P=0.747)$, while TAS was significantly decreased $(P<0.001)$. TOS and OSI in cases with disease duration greater than 2 years were more significantly increased than disease duration $\leq 2$ years $(P<0.001)$ (Table 2$)$.

On the basis of age, patients with $\mathrm{PD}$ and controls were divided into age group less than 50 years (Gp1: 32 subjects as cases and 24 subjects as controls), age group 50 to 59 years (Gp2: 124 subjects for cases and 75 subjects for controls), and age group more than 60 years (Gp3: 84 subjects for cases and 51 subjects for controls, Table 3 ). Observed PPA, TOS, TAS, and OSI values in cases and controls for age groups $<50$ years, 50-59 years, and $>60$ years were tabulated in Table 3.

In the cases, the differences of values of PPA, TOS, TAS, and OSI between male and female gender were nonsignificantly altered (data not shown). On the epidemiological analysis of the gender for the case group, out of total cases ( $n=240$, mean age $56.39 \pm 8.92$ years), it was observed that the number of males ( $n=180,75 \%$, and mean age $54.73 \pm$ 9.01 years) was three times greater than females ( $n=60,25 \%$, and mean age $61.37 \pm 6.71$ years). This data was divided into different age ranges, 35-39 (6, male; nil, female), 40-49 (26, male; 6 , female), $50-59$ ( 67 , male; 18 , female), and $60-70$ years (81, male; 36 , female).

\section{Discussion}

Proline deficiency in human leads to mental retardation and it is expected that this proline deficiency may be due to prolidase deficiency [17]. In our present study, it was observed that plasma prolidase activity was more decreased in patients with 
TABLE 2: Representation of PPA, TOS, TAS, and OSI with duration of disease in patients with PD.

\begin{tabular}{|c|c|c|c|c|c|}
\hline $\begin{array}{l}\text { Duration of Parkinson's } \\
\text { disease }\end{array}$ & $N(240)$ & $\begin{array}{c}\text { PPA } \\
\left(\mathrm{mmol} \mathrm{min}^{-1} \mathrm{~L}^{-1}\right)\end{array}$ & $\begin{array}{c}\text { TOS } \\
\left(\mu \mathrm{mol} \mathrm{H}_{2} \mathrm{O}_{2} \mathrm{Eq} / \mathrm{L}\right)\end{array}$ & $\begin{array}{c}\text { TAS } \\
(\mathrm{mmol} \text { Trolox Eq/L) }\end{array}$ & OSI (arbitrary unit) \\
\hline $\begin{array}{l}\leq 2 \text { years }(R=0.5 \text { to } 2.0 \\
\text { years })\end{array}$ & 140 & $43.13 \pm 29.89$ & $14.71 \pm 2.39$ & $1.98 \pm 0.38$ & $7.92 \pm 2.53$ \\
\hline $\begin{array}{l}>2 \text { years }(R=2.5 \text { to } 14.0 \\
\text { years })\end{array}$ & 100 & $38.44 \pm 25.43$ & $19.34 \pm 2.33$ & $1.27 \pm 0.16$ & $15.73 \pm 4.14$ \\
\hline$P$ value & & $0.747^{* *}$ & $<0.001^{*}$ & $<0.001^{*}$ & $<0.001^{*}$ \\
\hline
\end{tabular}

Significant (Sig.) $P$ value less than 0.05 was considered. Data are mean \pm standard deviation, $R=$ range, $*=$ value according to Student's $t$-test, and $* *=$ value according to Mann-Whitney $U$ test.

TABLE 3: Representation of PPA, TOS, TAS, and OSI in different age groups of cases and controls.

\begin{tabular}{|c|c|c|c|c|c|c|c|c|}
\hline \multirow[b]{2}{*}{ Parameters } & \multicolumn{3}{|c|}{ Cases $(n=240)$} & \multicolumn{5}{|c|}{ Controls $(n=150)$} \\
\hline & $\begin{array}{c}<50 \text { years } \\
(\mathrm{Gp} 1) \\
(n=38)\end{array}$ & $\begin{array}{c}\text { 50-59 years } \\
(\mathrm{Gp} 2) \\
(n=85)\end{array}$ & $\begin{array}{c}\geq 60 \text { years } \\
(\mathrm{Gp} 3) \\
(n=117)\end{array}$ & Sig. value & $\begin{array}{c}<50 \text { years } \\
(\mathrm{Gp} 1) \\
(n=24)\end{array}$ & $\begin{array}{c}50-59 \text { years } \\
(\mathrm{Gp} 2) \\
(n=51)\end{array}$ & $\begin{array}{c}\geq 60 \text { years } \\
(\mathrm{Gp} 3) \\
(n=75)\end{array}$ & Sig. value \\
\hline $\begin{array}{l}\text { PPA } \\
\text { mmol min }{ }^{-1} L^{-1}\end{array}$ & $28.06 \pm 34.29$ & $42.91 \pm 25.54$ & $37.12 \pm 29.86$ & $0.581^{* *}$ & $61.71 \pm 14.68$ & $55.51 \pm 13.57$ & $63.87 \pm 18.55$ & $0.527^{* *}$ \\
\hline $\begin{array}{l}\text { TOS } \\
\mu \mathrm{mol} \mathrm{H}_{2} \mathrm{O}_{2} \mathrm{Eq} / \mathrm{L}\end{array}$ & $13.30 \pm 3.02$ & $16.31 \pm 2.79$ & $17.26 \pm 3.91$ & $0.210^{*}$ & $12.57 \pm 2.60$ & $11.54 \pm 2.82$ & $13.04 \pm 2.48$ & $0.478^{*}$ \\
\hline $\begin{array}{l}\text { TAS } \\
\text { mmol Trolox Eq/L }\end{array}$ & $2.28 \pm 0.21$ & $1.72 \pm 0.46$ & $1.60 \pm 0.47$ & $0.130^{*}$ & $1.93 \pm 0.39$ & $2.01 \pm 0.43$ & $1.89 \pm 0.41$ & $0.837^{*}$ \\
\hline $\begin{array}{l}\text { OSI } \\
\text { Arbitrary unit }\end{array}$ & $5.91 \pm 1.87$ & $10.47 \pm 3.92$ & $12.40 \pm 6.38$ & $0.182^{* *}$ & $7.05 \pm 2.90$ & $6.27 \pm 3.18$ & $7.54 \pm 3.35$ & $0.643^{* *}$ \\
\hline
\end{tabular}

$\mathrm{Gp}=$ group, $n=$ numbers of subject, $*=$ values according to one-way ANOVA, and $* *=$ values according to Kruskal Wallis test.

PD than healthy subjects. Within PD patients, range of PPA was $1.47-88.45 \mathrm{mmol} \mathrm{min}{ }^{-1} \mathrm{~L}^{-1}$, while in healthy volunteers the range of PPA was 35.24-105.97 $\mathrm{mmol} \mathrm{min}^{-1} \mathrm{~L}^{-1}$ (Table 1).

Proline rich protein plays as key mediator of apoptosis and/or provides signal for induction of apoptosis [18], which leads to neuronal cells loss [19]. In present study we observed that plasma prolidase activity decreases with increase in duration of PD and may result in increase in concentration of proline rich dipeptides. It may lead to enhanced apoptotic signal and neuronal cell loss.

Polypeptide containing proline rich region plays a key role in aggresomes formation, while lack in proline rich region cannot allow the formation of aggresomes [20]. It has been reported that aggresomes formation leads to neuronal death in patients with PD [21, 22]. As our study suggests in the case of PD plasma prolidase activity decreases; thus it can increase the chance of accumulation of glycyl-1-proline peptides and other polypeptides containing c-terminal glycyll-proline, which may lead to aggresomes formation and neuronal death in patients with PD.

Most of neurofilaments (NF) proteins phosphorylation occurs in the carboxy-terminal tail domain of proline directed Ser/Thr residue [23]. NF of normal neurons has been predominantly phosphorylated in axonal region, while in the case of PD, NF proteins have been aberrantly hyperphosphorylated in the region of cell bodies [24]. It is seen that blockage of axonal transport in the cell body of neuron and neuronal cell death were observed with increase in NF phosphorylation [23]. Thus, it seems that proline in peptides is directly or indirectly involved in increasing signaling cascade for phosphorylation of NF proteins and finally leads to blockage of axonal transport and neuronal cell death. In our present study, we have observed decreased plasma prolidase activity in patients with $\mathrm{PD}$; thus the possibility of peptides containing c-terminal proline in body increases, which may be involved in increased phosphorylation and neuronal cell death.

Altered oxidative stress, mitochondrial dysfunction, inflammation, and environmental factor were reported in patients with $\operatorname{PD}[25,26]$. In normal situation of cellular system, oxidant and antioxidant production are balanced by different cellular reactions [27, 28]. The rates of production and destruction of oxidants and antioxidants are in balance state, referred to as oxidative balance. When levels of oxidants or antioxidants or both are altered, the situations of oxidative stress are developed [29]. Different research groups have described the altered levels of oxidants and antioxidants in the term of altered value of lipid peroxidation, reactive oxygen species, superoxide dismutase, glutathione, and reactive nitrogen species in the case of patients with PD [2527, 30]. Recently, Kirbas et al., 2014, have reported a study on paraoxonase, TAS, and TOS level in the patients with PD [13]. In our present study, we observed that status of PPA was nonsignificantly correlated to TOS and OSI in the patients with PD. Patients with PD have increased plasma TOS and OSI compared to healthy individuals, while PPA and TAS levels in patients with PD were significantly decreased as compared to normal healthy individuals $(P<0.01$, Table 1$)$.

PPA, TOS, TAS, and OSI are considered as oxidative stress markers for biological system. In general, prolonged 
increased oxidant level above the normal threshold leads to exhaustion and therefore decrease in antioxidant status in human. This leads to change in OSI value. In the case of patients with PD, we observed that decreased PPA was positively, linearly correlated to increase in TOS $(P=0.128)$ and OSI $(P=0.063)$, but all these were nonsignificant, while in patients with $\mathrm{PD}$, decreased TAS were negatively, linearly correlated to PPA which was significant $(P=0.047)$. Different investigators have reported that increased oxidants were related to decreased antioxidants in patients with $\mathrm{PD}$ $[10,22-24,27]$. On the same patterns, in patients with PD, we observed that increased TOS were linearly correlated to increased OSI $(P<0.001)$, while strong negative, linear correlations were observed between TOS and TAS $(P<$ $0.001)$. It should be noted that positive linear correlation between decreased PPA and increased TOS in patients with PD will need to be explored further for better clarification.

It is well accepted that increased oxidants and decreased antioxidants are associated with increase in age and lead to loss of neuron in brain and substantia nigra [25-28]. Hattiangady et al., 2010, have been reported that loss of neurons and cognitive functions was related to age [31]. Different investigators reported that neuronal cells loss was associated with increase in duration of Parkinson's disease [32]. In our present study, we observed that PPA and TAS in patients with PD were decreased with increase in duration of disease, while TOS and OSI were increased with increase in duration of disease (Table 2). Thus it seems that decreased PPA and TAS and increased TOS and OSI were associated with progression of disease and might be responsible for neuronal cell loss in patients with PD.

Results of oxidative stress markers were also analyzed in different age groups (Gp1, Gp2, and Gp3, Table 3) in patients with $\mathrm{PD}$ and healthy volunteers. We observed that age group $>60$ years (Gp3) has decreased PPA compared to age group between 50 and 59 years (Gp2) in patients with PD, indicating that higher age groups have decreased PPA status compared to lower age groups in patients with PD. On analysis of Table 3, it is concluded that higher age groups have increased TOS and OSI and decreased TAS compared to lower age groups in patients with $\mathrm{PD}$, but all are nonsignificant.

It is well accepted that higher age and male sex are more prone to PD. In American population, the onset of PD rarely occurs before the age of 40 years and the incidence of disease rapidly increased with rise in age (after 60 years) [33]. In our studied case group, all the patients with PD were selected from the two state of North India (Uttar Pradesh and Bihar), who attended the OPD of Sir Sunder Lal hospital, Institute of Medical Sciences, BHU, Varanasi, during the period of September, 2011, to August, 2014. In this study, $3: 1$ male and female ratio for Parkinson's disease was observed. It was also observed that early onset of PD for male was seen in age range of 35-39 years, while for female it was 40-49 years. Below 40 years' onset of PD for female was not observed. For $\mathrm{PD}$, the mean age of male was $54.73 \pm 9.01$ years, while for female it was $61.37 \pm 6.71$ years. Thus, males are more prone to $\mathrm{PD}$ in reference to gender, as well as at lower age, than female.

\section{Conclusions}

Results of our study concluded that plasma prolidase activity and total antioxidant status were significantly decreased while total oxidant status and oxidative stress index were significantly increased in the patients with PD as compared to healthy volunteers. With the increase in disease duration (progression of disease) PPA and TAS were decreased, while TOS and OSI were increased. With age, similar results are seen. Thus, the decreased status of PPA and increased oxidative stress were associated with progression of disease and higher age group and may be responsible for the pathogenesis of Parkinson's disease. On the epidemiological analysis of PD cases, it is concluded that males are more prone to early onset of PD.

\section{Conflict of Interests}

No conflict of interests exists.

\section{Acknowledgments}

Authors are thankful to all the subjects, who were enrolled and gave their consent for this study. Institute of Medical Sciences, Banaras Hindu University, Varanasi, India, has been highly acknowledged; Akhilesh Kumar Verma received IMSUGC-JRF/SRF fellowship and contingency.

\section{References}

[1] J. M. Savitt, V. L. Dawson, and T. M. Dawson, "Diagnosis and treatment of Parkinson disease: molecules to medicine," Journal of Clinical Investigation, vol. 116, no. 7, pp. 1744-1754, 2006.

[2] D. J. Moore, A. B. West, V. L. Dawson, and T. M. Dawson, "Molecular pathophysiology of Parkinson's disease," Annual Review of Neuroscience, vol. 28, pp. 57-87, 2005.

[3] M. F. Beal, "Mitochondria, oxidative damage, and inflammation in Parkinson's disease," Annals of the New York Academy of Sciences, vol. 991, pp. 120-131, 2003.

[4] E. C. Hirsch, S. Vyas, and S. Hunot, "Neuroinflammation in Parkinson's disease," Parkinsonism and Related Disorders, vol. 18, supplement 1, pp. S210-S212, 2012.

[5] A. Surażynski, W. Miltyk, J. Palka, and J. M. Phang, "Prolidasedependent regulation of collagen biosynthesis," Amino Acids, vol. 35, no. 4, pp. 731-738, 2008.

[6] I. Türkbeyler, T. Demir, Y. Pehlivan et al., "Prolidase could Act as a diagnosis and treatment mediator in lung fibrosis," Inflammation, vol. 35, no. 5, pp. 1747-1752, 2012.

[7] A. Arikanoglu, E. Akil, S. Varol et al., "Relationship of cognitive performance with prolidase and oxidative stress in Alzheimer disease," Neurological Sciences, vol. 34, no. 12, pp. 2117-2121, 2013.

[8] E. Uzar, Y. Tamam, O. Evliyaoglu et al., "Serum prolidase activity and oxidative status in patients with diabetic neuropathy," Neurological Sciences, vol. 33, no. 4, pp. 875-880, 2012.

[9] S. Selek, A. Altindag, G. Saracoglu, H. Celik, and N. Aksoy, "Prolidase activity and its diagnostic performance in bipolar disorder," Journal of Affective Disorders, vol. 129, no. 1-3, pp. 8486, 2011.

[10] A. B. Erbağci, M. Araz, M. Tarakçioğlu, and E. S. Namiduru, "Serum prolidase activity as a marker of osteoporosis in type 2 
diabetes mellitus," Clinical Biochemistry, vol. 35, no. 4, pp. 263268, 2002.

[11] S. Kumari, A. K. Verma, S. Rungta, R. Mitra, R. Srivastava, and N. Kumar, "Serum prolidase activity, oxidant and antioxidant status in nonulcer dyspepsia and healthy volunteers," ISRN Biochemistry, vol. 2013, Article ID 182601, 6 pages, 2013.

[12] D. Mantle, G. Falkous, S. Ishiura, P. J. Blanchard, and E. K. Perry, "Comparison of proline endopeptidase activity in brain tissue from normal cases and cases with Alzheimer's disease, Lewy body dementia, Parkinson's disease and Huntington's disease," Clinica Chimica Acta, vol. 249, no. 1-2, pp. 129-139, 1996.

[13] A. Kirbas, S. Kirbas, M. C. Cure, and A. Tufekci, "Paraoxonase and arylesterase activity and total oxidative/anti-oxidative status in patients with idiopathic Parkinson's disease," Journal of Clinical Neuroscience, vol. 21, no. 3, pp. 451-455, 2014.

[14] A. K. Verma, S. Chandra, R. G. Singh, T. B. Singh, S. Srivastava, and R. Srivastava, "Serum prolidase activity and oxidative stress in diabetic nephropathy and end stage renal disease: a correlative study with glucose and creatinine," Biochemistry Research International, vol. 2014, Article ID 291458, 7 pages, 2014.

[15] O. Erel, "A novel automated method to measure total antioxidant response against potent free radical reactions," Clinical Biochemistry, vol. 37, no. 2, pp. 112-119, 2004.

[16] O. Erel, "A new automated colorimetric method for measuring total oxidant status," Clinical Biochemistry, vol. 38, no. 12, pp. 1103-1111, 2005.

[17] H. Mitsubuchi, K. Nakamura, S. Matsumoto, and F. Endo, "Inborn errors of proline metabolism," Journal of Nutrition, vol. 138, no. 10, pp. 2016S-2020S, 2008.

[18] I. Gomes, W. Xiong, T. Miki, and M. R. Rosner, "A proline- and glutamine-rich protein promotes apoptosis in neuronal cells," Journal of Neurochemistry, vol. 73, no. 2, pp. 612-622, 1999.

[19] B. Pettmann and C. E. Henderson, "Neuronal cell death," Neuron, vol. 20, no. 4, pp. 633-647, 1998.

[20] Y. Wang, A. B. Meriin, N. Zaarur et al., "Abnormal proteins can form aggresome in yeast: aggresome-targeting signals and components of the machinery," The FASEB Journal, vol. 23, no. 2, pp. 451-463, 2009.

[21] M. Y. Sherman and A. L. Goldberg, "Cellular defenses against unfolded proteins: a cell biologist thinks about neurodegenerative diseases," Neuron, vol. 29, no. 1, pp. 15-32, 2001.

[22] K. S. P. McNaught, P. Shashidharan, D. P. Perl, P. Jenner, and C. W. Olanow, "Aggresome-related biogenesis of Lewy bodies," European Journal of Neuroscience, vol. 16, no. 11, pp. 2136-2148, 2002.

[23] T. B. Shea, Y.-L. Zheng, D. Ortiz, and H. C. Pant, "Cyclindependent kinase 5 increases perikaryal neurofilament phosphorylation and inhibits neurofilament axonal transport in response to oxidative stress," Journal of Neuroscience Research, vol. 76, no. 6, pp. 795-800, 2004.

[24] G. Sobue, Y. Hashizume, T. Yasuda et al., "Phosphorylated high molecular weight neurofilament protein in lower motor neurons in amyotrophic lateral sclerosis and other neurodegenerative diseases involving ventral horn cells," Acta Neuropathologica, vol. 79, no. 4, pp. 402-408, 1990.

[25] K. Ikeda, Y. Nakamura, T. Kiyozuka et al., "Serological profiles of urate, paraoxonase-1, ferritin and lipid in Parkinson's disease: changes linked to disease progression," Neurodegenerative Diseases, vol. 8, no. 4, pp. 252-258, 2011.
[26] R. L. Miller, M. James-Kracke, G. Y. Sun, and A. Y. Sun, "Oxidative and inflammatory pathways in Parkinson's disease," Neurochemical Research, vol. 34, no. 1, pp. 55-65, 2009.

[27] R. Betarbet, T. B. Sherer, and J. T. Greenamyre, "Ubiquitinproteasome system and Parkinson's diseases," Experimental Neurology, vol. 191, supplement 1, pp. S17-S27, 2005.

[28] P. L. Kok, H. H. Shan, R. de Silva, B. K. H. Tan, and Z. Z. Yi, "Oxidative stress: apoptosis in neuronal injury," Current Alzheimer Research, vol. 3, no. 4, pp. 327-337, 2006.

[29] M. Serafini and D. del Rio, "Understanding the association between dietary antioxidants, redox status and disease: is the total antioxidant capacity the right tool?" Redox Report, vol. 9, no. 3, pp. 145-152, 2004.

[30] A. Sharma, P. Kaur, B. Kumar, S. Prabhakar, and K. D. Gill, "Plasma lipid peroxidation and antioxidant status of Parkinson's disease patients in the Indian population," Parkinsonism and Related Disorders, vol. 14, no. 1, pp. 52-57, 2008.

[31] B. Hattiangady, R. Kuruba, and A. K. Shetty, "Acute seizures in old age leads to a greater loss of CA1 pyramidal neurons, an increased propensity for developing chronic TLE and a severe cognitive dysfunction," Aging and Disease, vol. 2, no. 1, pp. 1-17, 2011.

[32] H.-C. Cheng, C. M. Ulane, and R. E. Burke, "Clinical progression in Parkinson disease and the neurobiology of axons," Annals of Neurology, vol. 67, no. 6, pp. 715-725, 2010.

[33] S. K. van den Eeden, C. M. Tanner, A. L. Bernstein et al., "Incidence of Parkinson's disease: variation by age, gender, and race/ethnicity," The American Journal of Epidemiology, vol. 157, no. 11, pp. 1015-1022, 2003. 


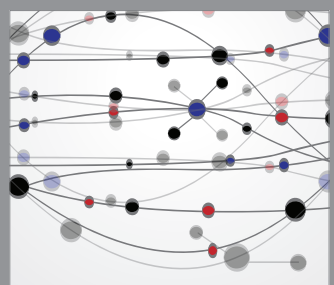

The Scientific World Journal
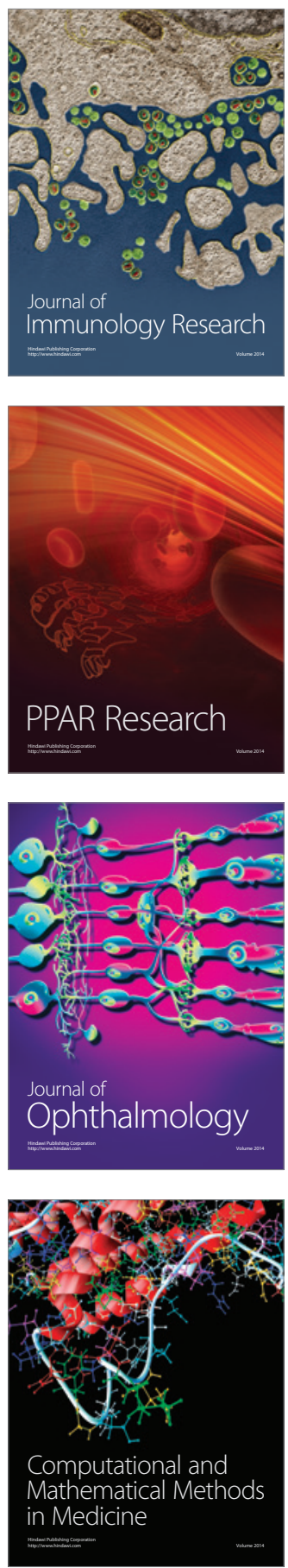

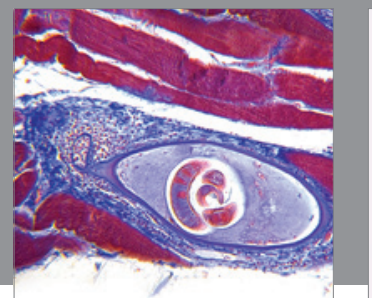

Gastroenterology

Research and Practice
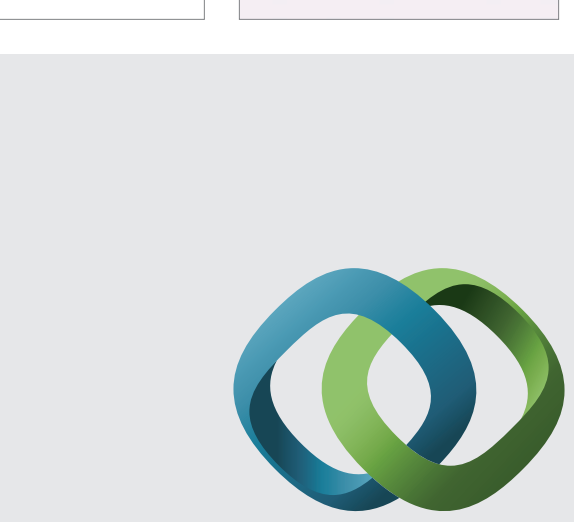

\section{Hindawi}

Submit your manuscripts at

http://www.hindawi.com
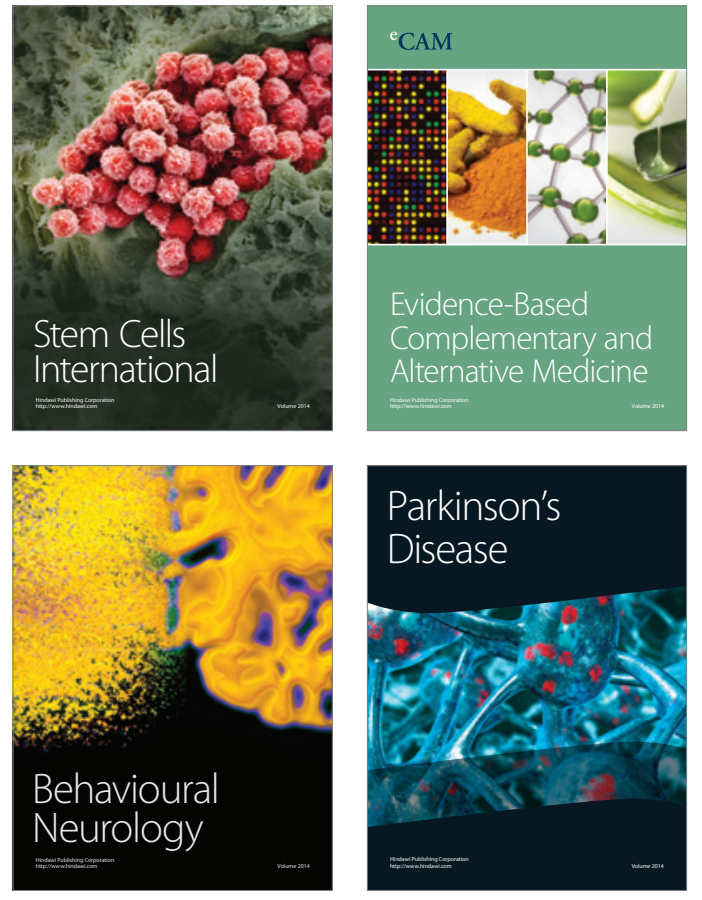
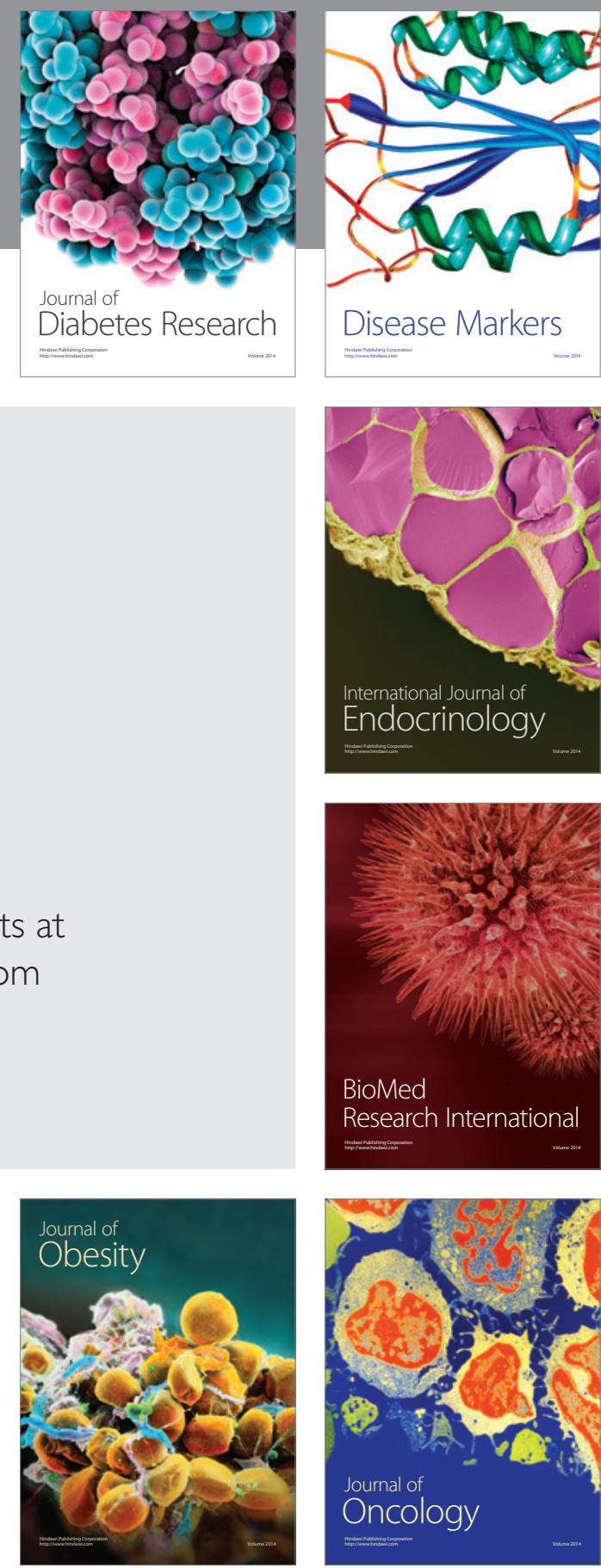

Disease Markers
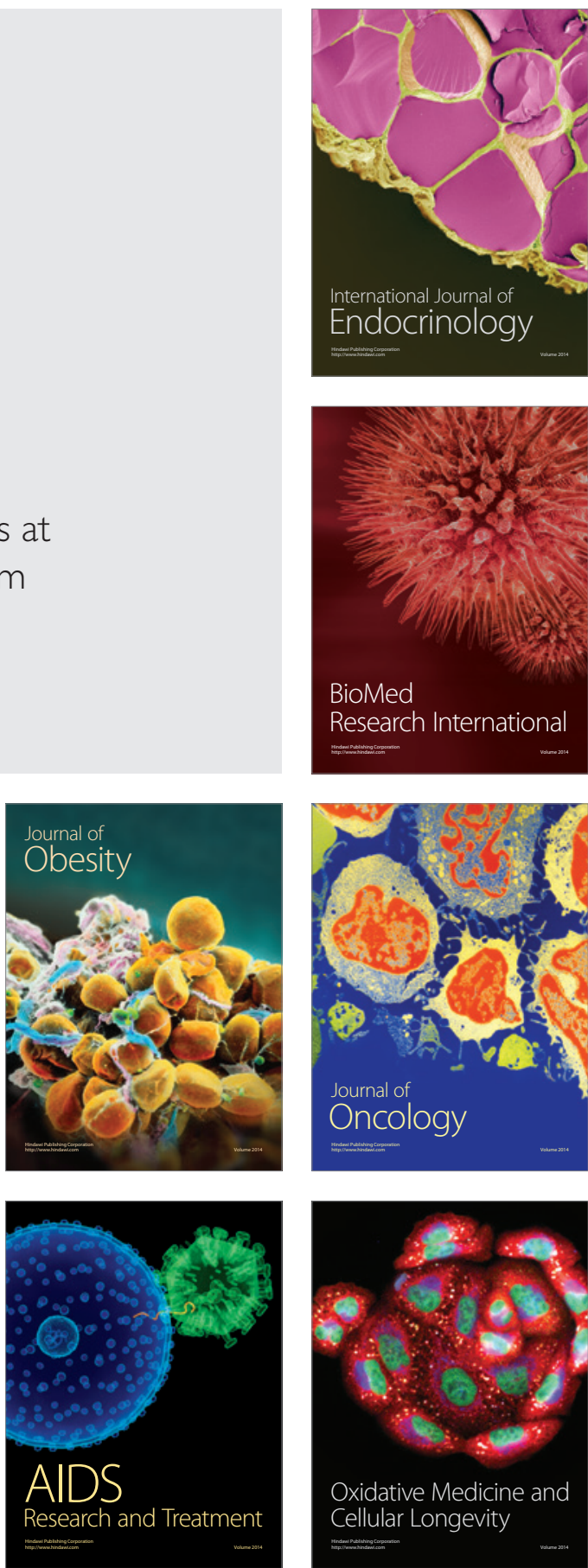